\title{
CHAPTER 2 \\ CYCLICAL NATURE OF DEVELOPMENT OF THE NATIONAL ECONOMY'S INNOVATIVE PROCESSES
}

\section{Verkhoglyadova N. I.}

\section{INTRODUCTION}

The problem of cyclical fluctuations in the economy was considered by scientists almost from the very beginning of the existence of economic science. A. Smith, who proposed the concept of economic growth, relied on the fact that it is ensured by technological progress as a result of the growing division of labor. The idea of A. Smith about the flexibility of salaries and prices formed the basis of the crisis-free growth theory of J. Say and D. Ricardo. On the other hand, T. Malthus and K. Marx put forward directly opposite theories. According to Malthus, a sufficient level of demand in the economy is unattainable without the participation of a third party .K. Marx believed that the limiting factor, which is leading to the alternation of periods of economic growth and decline, is the limited consumption of the masses, which counteracts the desire of the capitalists to develop productive forces.

At the heart of most modern cyclical theories in economics is the concept of an accelerator multiplier, put forward by neoKeynesians.According to representatives of this direction in economic science, crisis-free economic growth is possible if the state will provide the correct policy concerning the regulation of the so-called "supercumulative" effect, based on the action of both the multiplier and accelerator effects ${ }^{1}$. The famous economist N. Kondrat'ev put forward the idea that long-term economic fluctuations ("long waves") arise as a result of changes in production technologies as a result of scientific and technological progress ${ }^{2}$. Economists F. Kidland and A. Prescott consider that stochastic shocks caused by fluctuations in aggregate labor productivity are the source of cyclical fluctuations in the economy. Their researches about the problems of economic cycles took into account the totality of stochastic (probabilistic) macroeconomic factors and created

\footnotetext{
${ }^{1}$ Blauh M. (2001). Ekonomichna teoriia v retrospektyvi [Economic theory in retrospect]. Kyiv : Osnovy, 672 p.

${ }^{2}$ Kondratev N.D. (1993). Izbrannyie sochineniya [Selected Works]. Moskva : Ekonomika, 544 p.
} 
the prerequisites for a deeper understanding of important aspects of the essence, patterns of development and functioning of economic cycles ${ }^{3}$.

Global changes taking place in the economic life of society are manifested before and at the beginning of the rising wave of each economic cycle and consist in global changes in the technical and technological equipment of production, the attraction of new countries to world economic relations and changes in money circulation, which in turn are reflected on the course of innovative processes of national economies. The main role in the cyclical nature and patterns of such changes belongs to innovation.

In modern conditions, the study of the dynamics of innovative activity and the preparation of a further forecast of the course of innovative processes and the functioning of enterprises, which are active in this field is especially actually, since it allows us to suggest possible fluctuations and develop recommendations for their prevention with the aim to the progressive development of the economy as a whole. Fluctuations can occur in a large number of dynamic indicators, while some indicators may not reflect them. In this regard, the development and usage of a system of indicators of the cyclical economy are an integral part of the analysis of innovative processes.

Analysis of innovation activity cycles for the modern Ukrainian economy is a fairly relevant area of applied economic research.

The word "innovation" is derived from the verb "innovate", meaning "to modify or modernize", which reflects the basic idea of innovation, which is to upgrade.

Moreover, the innovation process is the process of converting scientific knowledge into innovation, which can be represented as a sequential series of changes from the emergence of an idea to the final product and its further commercialization aimed at the effective functioning of all constituent elements ${ }^{4}$.

The cyclical nature of innovation processes depends on the uneven implementation of innovations, and this, in turn, is due to the impact on the innovation process of a large number of factors, the systematization and timely identification of which will make it possible to predict the development of innovative processes in the national economy, given the

\footnotetext{
${ }^{3}$ Balashova E. (2005). Finn Kyudland i Edvard Preskott: dvizhuschie silyi eko-nomicheskih tsiklov [Finn Cudland and Edward Prescott: drivers of economic cycle]. Voprosyi ekonomiki, no. 1, pp. 133-143.

${ }^{4}$ Beketov N.V. (2008). Tsiklichnost razvitiya ekonomicheskoy sistemyi i innovatsionnyie otnosheniya $\mathrm{v}$ konkurentnoy srede [The cyclical development of the economic system and innovative relations in a competitive environment]. Vestnik HGAEP, no. 1(34), pp. 4-11.
} 
fact that the creation of favorable external conditions is necessary for the innovation process, contributing to innovative development.

Factor (from lat. factor - doing, producing) - the reason, the driving force of any process, which determines the nature of its individual features.

Factors of innovative development can be divided into stagnant (slowing down) and stimulating; by the level of influence - factors affecting the global, macro-, meso- and micro-levels ${ }^{5}$.

In our opinion, it should be singled out separately the groups of factors that contribute to the development of innovative processes and prevent it. In each of these groups, it is possible to distinguish economic, technological and political-legal factors (Table 1).

Table 1

Factors contributing to and impeding the innovation

\begin{tabular}{|l|l|l|}
\hline \multicolumn{1}{|c|}{$\begin{array}{c}\text { Group of } \\
\text { factors }\end{array}$} & $\begin{array}{l}\text { Factors, which imped the } \\
\text { innovation activity }\end{array}$ & $\begin{array}{l}\text { Factors, which contribute to } \\
\text { the innovation activity }\end{array}$ \\
\hline $\begin{array}{l}\text { Economic- } \\
\text { technological }\end{array}$ & $\begin{array}{l}\text { Lack of funds to finance } \\
\text { innovative projects, } \\
\text { imperfection or obsolescence } \\
\text { of the material and scientific- } \\
\text { technical base, lack of reserve } \\
\text { capacities, dominance of the } \\
\text { interests of current } \\
\text { production. }\end{array}$ & $\begin{array}{l}\text { The presence of a reserve of } \\
\text { financial and material and } \\
\text { technical means, advanced } \\
\text { technologies, the necessary } \\
\text { economic and scientific- } \\
\text { technical infrastructure. }\end{array}$ \\
\hline Political-legal & $\begin{array}{l}\text { Restrictions on antitrust, tax, } \\
\text { depreciation, patent and } \\
\text { licensing laws. }\end{array}$ & $\begin{array}{l}\text { Legislative measures } \\
\text { (especially incentives) that } \\
\text { encourage innovation, } \\
\text { government support for } \\
\text { innovation }\end{array}$ \\
\hline
\end{tabular}

In addition to the factors above, the cyclical nature of innovation is also influenced by institutional factors (Table 2).

Factors affecting the innovation process and its cyclical nature include two groups:

- the innovation cycle, particularly, the duration and amplitude of fluctuations;

- cyclical nature of innovation.

\footnotetext{
${ }^{5}$ Beketov N.V. (2008). Tsiklichnost razvitiya ekonomicheskoy sistemyi i innovatsionnyie otnosheniya $\mathrm{v}$ konkurentnoy srede [The cyclical development of the economic system and innovative relations in a competitive environment]. Vestnik HGAEP, no. 1(34), pp. 4-11.
} 
Table 2

Institutional factors of innovation cyclical nature

\begin{tabular}{|l|l|}
\hline \multicolumn{1}{|c|}{ Factor } & \multicolumn{1}{|c|}{ Characteristics } \\
\hline $\begin{array}{l}\text { 1. Legislative and legal norms in } \\
\text { the field of innovation. }\end{array}$ & $\begin{array}{l}\text { This factor includes a well-developed } \\
\text { system of legislative and other acts of all } \\
\text { levels of the hierarchy, providing } \\
\text { economic entities with the necessary tools } \\
\text { for concluding and observing contracts } \\
\text { with minimal costs. }\end{array}$ \\
\hline $\begin{array}{l}\text { 2. The system of public } \\
\text { administration of the innovation } \\
\text { process }\end{array}$ & $\begin{array}{l}\text { The organization of this system should } \\
\text { provide all economic operators with equal } \\
\text { access to resources, as well as contribute to } \\
\text { the specification of property rights. }\end{array}$ \\
\hline $\begin{array}{l}\text { 3. Innovation market } \\
\text { infrastructure: } \\
\text { - financial system; } \\
\text { - credit ensuring system; } \\
\text { - media system. }\end{array}$ & $\begin{array}{l}\text { This factor provides a relationship between } \\
\text { all economic entities and is an important } \\
\text { element of their interaction, a tool to } \\
\text { reduce transaction costs; influences public } \\
\text { opinion, thus represents a management } \\
\text { tool for stimulating the search for } \\
\text { innovations and their implementation }\end{array}$ \\
\hline $\begin{array}{l}\text { 4. The system of cultural, } \\
\text { religious values and behavioral } \\
\text { characteristics of innovators and } \\
\text { consumers of innovations. }\end{array}$ & $\begin{array}{l}\text { This group of factors determines the } \\
\text { configuration of institutions and allows to } \\
\text { predict the results of institutional changes, } \\
\text { as well as sets the direction of the } \\
\text { institutional development of innovations. }\end{array}$ \\
\hline
\end{tabular}

The cycle time depends on the factors of the first group, which include such as the amount of capital and its compliance to needs, the presence of demand for a new product, the level of inflation, the activity of sales of a new product to the saturation point, personnel and pricing policies.

Factors that, in turn, determine the amplitude of fluctuations in the innovation process include production volumes, advertising costs, and marketing.

The second group of factors that affect the cyclical nature of innovations is proposed to be considered within the framework of cyclical phases, the detailed characteristic of which is presented in table 4.

Today there is no single interpretation of the cyclical phase. In our opinion, the cyclic phase is a period from one peak point to another, the change of which occurs under the influence of certain factors. 
Factors affecting the innovation cycle

\begin{tabular}{|l|l|}
\hline \multicolumn{1}{|c|}{ Sign } & \multicolumn{1}{c|}{ Factor } \\
\hline Cycle duration & $\begin{array}{l}\text { The volume of capital and its relevance to } \\
\text { demand, the presence of demand for a } \\
\text { new product, inflation, sales activity of a } \\
\text { new product to the saturation point, } \\
\text { personnel and pricing policies }\end{array}$ \\
\hline Fluctuations' amplitude & $\begin{array}{l}\text { Volumes of production. Costs of } \\
\text { advertising and marketing of products }\end{array}$ \\
\hline
\end{tabular}

Factors affecting the cyclical nature of innovations, in our opinion, should be grouped according to the cyclical phases.

Innovations translate the economic situation from decreasing to an increasing trend, while their distribution over time stretches occurs unevenly. Part of the explanation for the economic fluctuations comes down to technical innovations and improvements to the introduction of resources in exploitation, as well as the development of new territorial segments. The phases of innovation cycles include growth, peak, stagnation, decline, depression ${ }^{6}$. The characteristics of the factors affecting the cyclical nature of innovation are presented in table 4.

Table 4

Factors affecting the cycle nature of innovation

\begin{tabular}{|c|l|}
\hline Phase of the cycle & \multicolumn{1}{c|}{ Factors } \\
\hline Growth (rise) & $\begin{array}{l}\text { Increasing of demand, production, credit expansion, } \\
\text { rising of inflation and nominal interest rates, high } \\
\text { innovation activity to implement inventions, which } \\
\text { were made in the fall and depression phases. Rapid } \\
\text { growth of new industries. Opening and rapid develop- } \\
\text { ment of new markets, stimulation of competition. }\end{array}$ \\
\hline Peak(vertex) & $\begin{array}{l}\text { Price stabilization, low inflation level, production } \\
\text { intensification, high level of employment. }\end{array}$ \\
\hline Stagnation (standstill) & $\begin{array}{l}\text { A sharp splashin prices and interest rates, the } \\
\text { transition of inflation to hyperinflation, high patent } \\
\text { activity (inventions are reduced to small } \\
\text { improvements), overproduction of means of } \\
\text { production. }\end{array}$ \\
\hline
\end{tabular}

${ }^{6}$ Zamulin O. (2005). Kontseptsiya realnyih ekonomicheskih tsiklov i ee rol v evolyutsii makroekonomicheskoy teorii [The concept of real economic cycles and its role in the evolution of macroeconomic theory]. Voprosyi ekonomiki, no. 1, pp. 144-152. 


\begin{tabular}{|l|l|}
\hline Phase of the cycle & \multicolumn{1}{|c|}{ Factors } \\
\hline Fall (descent) & $\begin{array}{l}\text { Decrease the inflation, real and nominal rates, } \\
\text { predominance of portfolio investments, decrease in } \\
\text { demand, increase of protectionism, falling of prices } \\
\text { and production in monopolized industries. }\end{array}$ \\
\hline Depression (crisis) & $\begin{array}{l}\text { Zero interest rates, low demand, the release of } \\
\text { resources and high unemployment, the creation of } \\
\text { important inventions, which will be implemented } \\
\text { almost simultaneously at the beginning of the growth } \\
\text { phase and will create new industries and a new } \\
\text { technological style. }\end{array}$ \\
\hline
\end{tabular}

Such grouping of factors allows identifying weak links in the structure of the innovation process to formulate a targeted innovation policy.

The detailed characterization of the factors presented in table 4 more fully shows the cyclical nature of innovation processes.

Thus, identifying the factors influencing the innovation cycle in a particular phase of the cyclicality of innovations allows us to determine a set of measures that correct or stimulate innovation processes, if necessary, and to identify those periods when the pace of technological progress exceeds the expected results.

As we consider innovative processes, it can be said that, ultimately, the cause of the cyclicality of innovation processes is the emergence in the depression phase of important inventions, which are subsequently introduced in the growth phase, and factors that directly affect each phase of cyclicality also play their role in cycles duration? ${ }^{7}$.

\subsection{The system of indicators of cyclicality and features of its application}

The system of cyclicality indicators is widely used by international research institutes in different countries for analyzing business cycles and forecasting their turning points.

Indicators are readily observable and measurable characteristics of the object being studied that reflect changes occurring with it.

The description of the indicator in the most general case should include:

\footnotetext{
${ }^{7}$ Zarova E.V. (2010). Statisticheskie indikatoryi kratkosrochnyih ekonomicheskih tsiklov v razvitii regiona : monografiya [Statistical indicators of short-term economic cycles in the development of the region: monograph]. Samara : Izd-vo Samar. gos. ekon. un-ta, 215 p.
} 
- definition (an accurate and unambiguous answer to the question of what this indicator is);

- a tool for measuring this indicator;

- frequency of measurement;

Besides, the description of the indicator may include:

- a description of what exactly this indicator measures. It may be necessary if the definition does not provide sufficient information for users;

- a brief description of the measurement methodology (answer to the question of how to determine the value of the indicator). It may be necessary to perform a measurement using a recommended technique or tool;

- advantages and strengths of this indicator, as well as limitations concerning its usage. These characteristics of the indicator are refined as it is used. They may be needed for further interpretation of the data and for improvement of the indicator system.

Under the system of indicators, we understand a set of indicators that can interpret the change in the state of the object under study. Depending on the object of measurement, it is distinguished systems of indicators of resources, process, a direct result, overall result, influence ${ }^{8}$.

As a result of the analysis of foreign experience, the next requirements to the system of indicators were identified:

- possibility of quantitative expression;

- ability to use statistics;

- low costs for information gathering and calculations;

- ability to evaluate the change in the state of an object in time;

- possibility of matchings and comparisons with other similar objects.

In the international practice of economic cycle research, the industrial production index (IPI) is considered the most suitable indicator for measuring overall economic activity. This indicator is used to identify cycle turning points in many countries ${ }^{9}$. The choice of this indicator as a base range is primarily explained because it is available monthly in most countries, therefore, the industrial production index best reflects the cyclical nature of the entire economic system. Of course, it would be more preferable to use the GDP indicator as to the base

\footnotetext{
${ }^{8}$ Makarenko I.P. Nekotoryie instrumentyi prognoza ekonomicheskoy dinamiki i ekonomicheskih krizisov [Some tools for forecasting economic dynamics and economic crises]. URL: http://http://www.iee.org.ua/ (accessed: 10.06.2019).

${ }^{9}$ Yakovets Yu.V. (1999). Tsiklyi. Krizisyi. Prognozyi [Cycles. Crises. Forecasts]. Moskva : Nauka, $448 \mathrm{p}$.
} 
dynamic row, but in many countries, the GDP is calculated only by a year or quarterly and published very late. In addition, a long observation showed that the graphs of the IPI cycles and GDP are interrelated, therefore, cyclical indicators based on the industrial production index can also serve as cycle indicators for GDP.

The methodology for obtaining cyclical indicators based on the dynamic range of economic indicators was developed mainly at the National Bureau of Economic Research (NBER) in the United States. In the work of the NBER, business activity cycles are defined as a periodically repeating sequence of phases of increasing and decreasing levels of a large number of economic and financial indicators. These cyclic fluctuations occur continuously, and the duration of the cycle is usually several years ${ }^{10}$.

Nowadays, there are systems of indicators that reflect one or another phase of the business cycle in the state of the national economy - a system of cyclical indicators. According to N. Petukhov, these same cyclical systems can be successfully applied to determine the cyclical nature of the innovation process. Innovations affect technology at all phases of their life cycle, which in turn will affect the socioeconomic system as a whole ${ }^{11}$.

Along with the basic dynamic range, cyclic indicators are divided into three groups of indicators:

- "leading";

- "matching (synchronous)";

- "delayed".

In most countries, a group of "matching" indicators, the basic dynamic range of which is the dynamics of macroeconomic indicators, which are combined into a composite index.

Some cyclical indicators are not equally successfully applied for different countries due to differences in the structure of the economies of these countries, the rules, and traditions of statistical accounting.

At the same time, along with "matching" indicators, national systems of so-called "leading" indicators are widespread in international practice, the dynamics of which are "ahead" of the dynamics of "matching" indicators.

\footnotetext{
${ }^{10}$ Zamulin O. (2005). Kontseptsiya realnyih ekonomicheskih tsiklov i ee rol v evolyutsii makroekonomicheskoy teorii [The concept of real economic cycles and its role in the evolution of macroeconomic theory]. Voprosyi ekonomiki, no. 1, pp. 144-152.

${ }^{11}$ Petuhov N.A. (2012). Innovatsionnyie faktoryi razvitiya sovremennyih ekonomicheskih sistem: avtoref. ... kand. ekon. nauk: 08.00.05. Krasnodar. URL: http://rudocs.exdat.com/docs/index527491.html (data zvernennya: 14.11.2019).
} 
Indicators that make up the category of "leading ones" are also selected based on the following criteria: relevance, cyclicality in change, practical application.

Moreover, relevance is determined by the following factors:

- economic significance, that is, there must be a reason of economic nature for the indicator to influence the cycle, only then the dynamic range of this indicator, and, therefore, the indicator itself can be accepted as "leading";

- the degree of coverage of innovation processes with this indicator, in which ranges with wide coverage from representativeness of the corresponding sphere of economic activity are preferable in comparison with ranges with narrow coverage.

The cyclicity in change is characterized by:

- the duration and sequence of advancing the indicator value over the base cycle at turning points;

- cyclic correspondence between the indicator and the base range - in the case of a large relationship between the cyclic behavior, the indicator will be a guideline, not only indicating turning points but also changes during the entire cycle;

- the absence of additional cycles or missing cycles: in comparison with the basic time range;

- smoothness in cyclic dynamics, so that it is possible to distinguish cyclical changes in the dynamic series from random movements.

The practical application of such indicators is based on:

- the lightness of collection and updating of necessary information;

- frequency of publications (in particular, monthly publications are preferable to quarterly ones); data;

- the absence of large differences between preliminary and final

- the availability of information series for a long time without omissions.

It is believed that when selecting possible cyclical "leading" indicators, the determining criterion is economic significance. Moreover, to choose the dynamic range as a cyclical "leading" indicator, there must be an economic logic for the relationship of this indicator with the cycle $^{12}$.

\footnotetext{
${ }^{12}$ Haberler G. (2005). Protsvetanie i depressiya: teoreticheskiy analiz tsiklicheskih kolebaniy [Prosperity and depression: a theoretical analysis of cyclic vibrations]. Chelyabinsk : Sotsium, $474 \mathrm{p}$.
} 
Economic "leading" indicators are classified into the following categories:

1) indicators that respond at an early stage;

2) quickly responding indicators;

3) indicators, which are sensitive to economic expectations;

4) indicators, driving other indicators;

5) other indicators.

An important element in the analysis of innovation activity cycles is the construction of composite (composite) indicators. This entails the combination of cyclic indicators into a single synthetic indicator. Such composite indicators are designed to weaken the so-called «false signals» (random fluctuations) and give the composite indicator better tracking and predictive properties than any of the components.

As far as components of the composite indicator are not completely correlated, composite indicators reduce the "false signals" caused by measurement errors.

The most important step in the study of the cyclical nature of the innovative activity is the determination of the cycle duration and dates of peaks and dimples, the so-called peak changes.

To determine the tipping points of the cycle, the US NBER methodology is used, according to which the moment of change in the cycle is selected based on the following criteria: the phase duration should be at least five months, and the cycle duration should be at least 15 months if you consider the length of time from the peak or from one lowest point of the cycle to another.

One of the main goals of using systems of cyclic indicators is the prediction of turning points since all market participants need to know the economic situation at any given moment.

In our opinion, all these systems can also be used to measure the activity of innovation processes, because the innovation process itself is one of the indicators of business activity in the economy.

Currently, it seems relevant to determine the set of indicators that optimally reflects the cyclical nature of innovation processes. Using just one indicator for these purposes is not enough.

According to the theses mentioned above, we have formed table 5, which characterizes the indicators of cyclical innovation processes.

This table gives opportunity to choose a specific type or form a composite indicator of the cyclical nature of innovative processes, which, in our opinion, is the most optimal for predicting innovation in the economy. 
Indicators of cyclical innovation processes

\begin{tabular}{|l|l|}
\hline \multicolumn{1}{|c|}{ Type } & \multicolumn{1}{c|}{ Characteristic } \\
\hline Leading & $\begin{array}{l}\text { Indicators, which help to predict beforehand the } \\
\text { innovation fluctuations }\end{array}$ \\
\hline Matching & $\begin{array}{l}\text { Indicators, which confirm the real fluctuation of } \\
\text { innovative activity }\end{array}$ \\
\hline Delayed & $\begin{array}{l}\text { Indicators, confirming fluctuations in innovation } \\
\text { activity }\end{array}$ \\
\hline
\end{tabular}

We propose to form a composite indicator of the cyclical nature of the innovation process of the national economy using the input (resource), functional (resultative) and perspective (activity indicators) indicators. The composition of indicators of each group can be formed using correlation and regression analysis by selecting the most significant ones that will reflect the cyclical nature.

The most commonly used types of models are ${ }^{13}$ :

1. with steady development - linear: $\mathrm{Y}_{\mathrm{t}}=\mathrm{b}_{0}+\mathrm{b}_{1} \mathrm{t}+\mathrm{b}_{2} \mathrm{t}_{2}$;

2. with growth with acceleration:

a. second-order parabola: $Y_{t}=b_{0}+b_{1} t+b_{2} t_{2}$;

b. cubic parabola: $Y_{t}=b_{0}+b_{1} t+b_{2} t_{2}+b_{3} t_{3}$;

3. at constant growth rates - indicative: $Y_{t}=b_{0} b_{1} t$;

4. with a decrease with deceleration - hyperbolic: $Y_{t}=b_{0}+b_{1} \times 1 / t$.

We propose to present a composite indicator of the cyclical nature of the innovation process of the national economy in its initial linear form:

$$
I_{c}=a_{1} I_{i}+a_{2} I_{f}+a_{3} I_{p}
$$

where $I_{c}-$ is the composite cyclical indicator;

$a_{1}, a_{2,} a_{3}$ - weighting coefficients of indicators;

$I_{i}-$ incoming indicator;

$I_{f}$ - functional indicator;

$I_{p}-$ perspective indicator.

The input indicators of the cyclical nature of the innovation process, on our opinion, include indicators of sources of financing the innovation.

The list of functional indicators includes indicators of the development, implementation and realization of innovation.

\footnotetext{
${ }^{13}$ Zarova E.V. (2010). Statisticheskie indikatoryi kratkosrochnyih ekonomicheskih tsiklov v razvitii regiona : monografiya [Statistical indicators of short-term economic cycles in the development of the region: monograph]. Samara : Izd-vo Samar. gos. ekon. un-ta, 215 p.
} 
Prospective indicators include indicators of innovative activity.

Moreover, depending on the analysis period, the type of model for forecasting may be different.

Thus, the correct choice of cyclical indicators is a prerequisite for successfully predicting fluctuations in innovation activity in the economy.

\subsection{Analytical assessment of the cyclical factors of innovative processes in the economy of Ukraine for 2000-2018}

Today, the situation in Ukraine is the next. Although economic parameters show better movement than planned, the innovation situation, unfortunately, remains unstable, especially the situation with financing innovation is deplorable (tab. 6).

Table 6

\section{Sources of financing innovation in Ukraine ${ }^{14}$}

\begin{tabular}{|c|c|c|c|c|c|}
\hline & \multirow{2}{*}{$\begin{array}{c}\text { Costs for } \\
\text { innovation, }\end{array}$} & \multicolumn{4}{|c|}{ Including from the expense of funds } \\
\cline { 3 - 6 } & own & $\begin{array}{c}\text { state } \\
\text { budget }\end{array}$ & $\begin{array}{c}\text { non-resident } \\
\text { investors }\end{array}$ & $\begin{array}{c}\text { other } \\
\text { sources }\end{array}$ \\
\hline 2000 & 1757,1 & 1399,3 & 7,7 & 133,1 & 217,0 \\
\hline 2001 & 1971,4 & 1654,0 & 55,8 & 58,5 & 203,1 \\
\hline 2002 & 3013,8 & 2141,8 & 45,5 & 264,1 & 562,4 \\
\hline 2003 & 3059,8 & 2148,4 & 93,0 & 130,0 & 688,4 \\
\hline 2004 & 4534,6 & 3501,5 & 63,4 & 112,4 & 857,3 \\
\hline 2005 & 5751,6 & 5045,4 & 28,1 & 157,9 & 520,2 \\
\hline 2006 & 6160,0 & 5211,4 & 114,4 & 176,2 & 658,0 \\
\hline 2007 & 10821,0 & 7969,7 & 144,8 & 321,8 & 2384,7 \\
\hline 2008 & 11994,2 & 7264,0 & 336,9 & 115,4 & 4277,9 \\
\hline 2009 & 7949,9 & 5169,4 & 127,0 & 1512,9 & 1140,6 \\
\hline 2010 & 8045,5 & 4775,2 & 87,0 & 2411,4 & 771,9 \\
\hline 2011 & 14333,9 & 7585,6 & 149,2 & 56,9 & 6542,2 \\
\hline 2012 & 11480,6 & 7335,9 & 224,3 & 994,8 & 2925,6 \\
\hline 2013 & 9562,6 & 6973,4 & 24,7 & 1253,2 & 1311,3 \\
\hline 2014 & 7695,9 & 6540,3 & 344,1 & 138,7 & 672,8 \\
\hline 2015 & 13813,7 & 13427,0 & 55,1 & 58,6 & 273,0 \\
\hline 2016 & 23229,5 & 22036,0 & 179,0 & 23,4 & 991,1 \\
\hline 2017 & 9117,5 & 7704,1 & 227,3 & 107,8 & 1078,3 \\
\hline 2018 & 12180,1 & 10742,0 & 639,1 & 107,0 & 692,0 \\
\hline
\end{tabular}

\footnotetext{
${ }^{14}$ Derzhavna sluzhba statystyky Ukrainy [State Statistics Service of Ukraine]. URL: http://www.ukrstat.gov.ua (accessed: 07.10.2019).
} 
If we look at the chart above, we will see that the peak points of the innovation cycle in the cost of innovation are those years that preceded the crisis in the economy.

At the same time, if you consider the sources of financing, you can see the next situation (Figure 1).

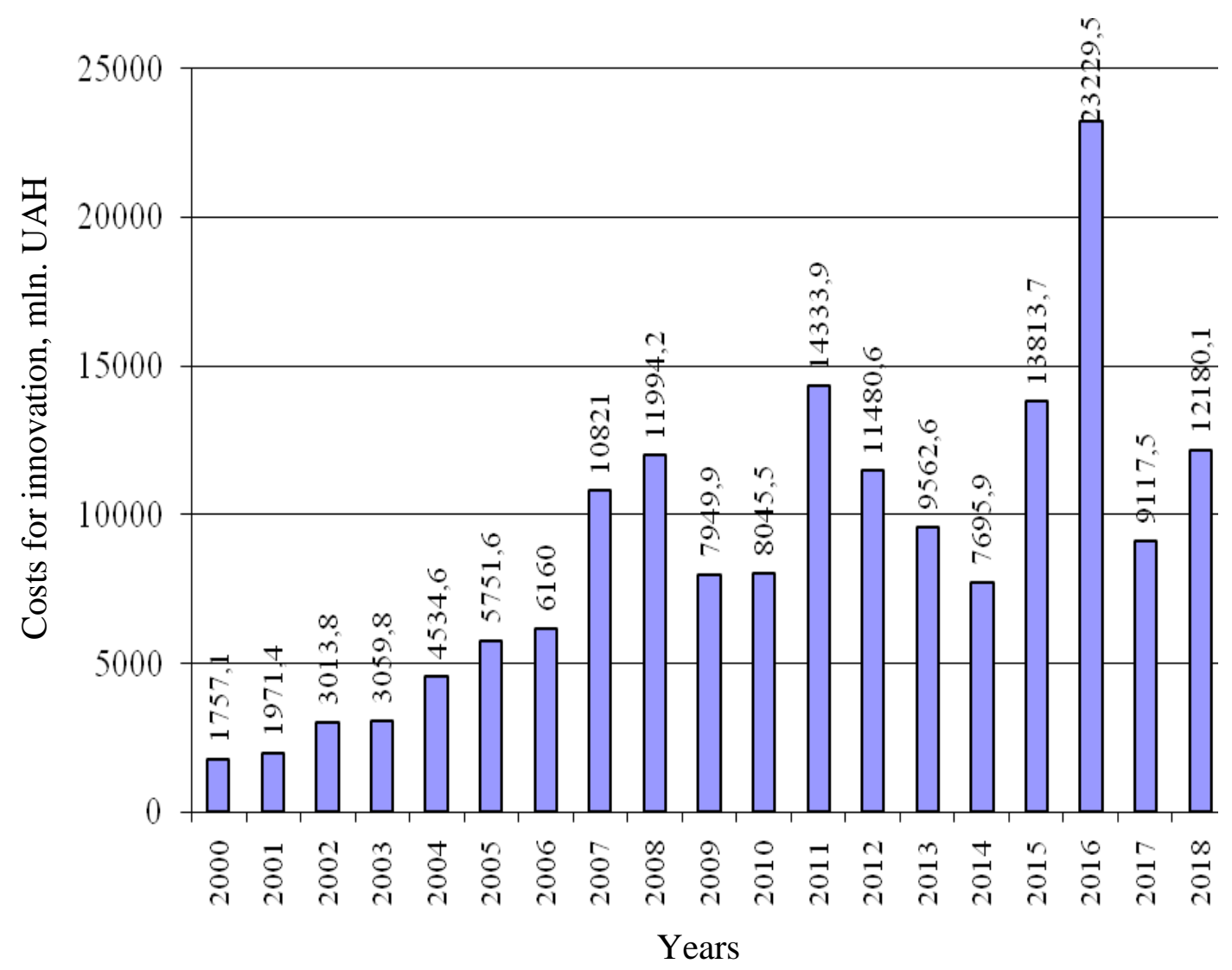

Figure 1. Dynamics of costs for innovation, mln. UAH

Peak periods of the innovation costs growth were 2008, 2011 and 2016.

The result shows that the progressive development of the innovation process of the national economy of Ukraine (2000-2018) prevails in the analyzed period. The state of overall development of the innovation process in Ukraine is characterized by an immediate increase in the rate of growth of indicators of the resource direction, which is followed by a sharp decline. Based on the results obtained, we can predict the following phases of the innovation cost cycle in the future: 2019-2020 - sustained growth, 2021-2023 - the fall and the depression, 2023 - the revival, 2024 - the peak of the growth of the innovation cost and the beginning of a new cycle. 
Regarding the dynamics of the cost of innovation by funding sources, it is possible to distinguish the sharp growth in 2016 and the same sharp decline in 2017 from own funds (Figure 2).

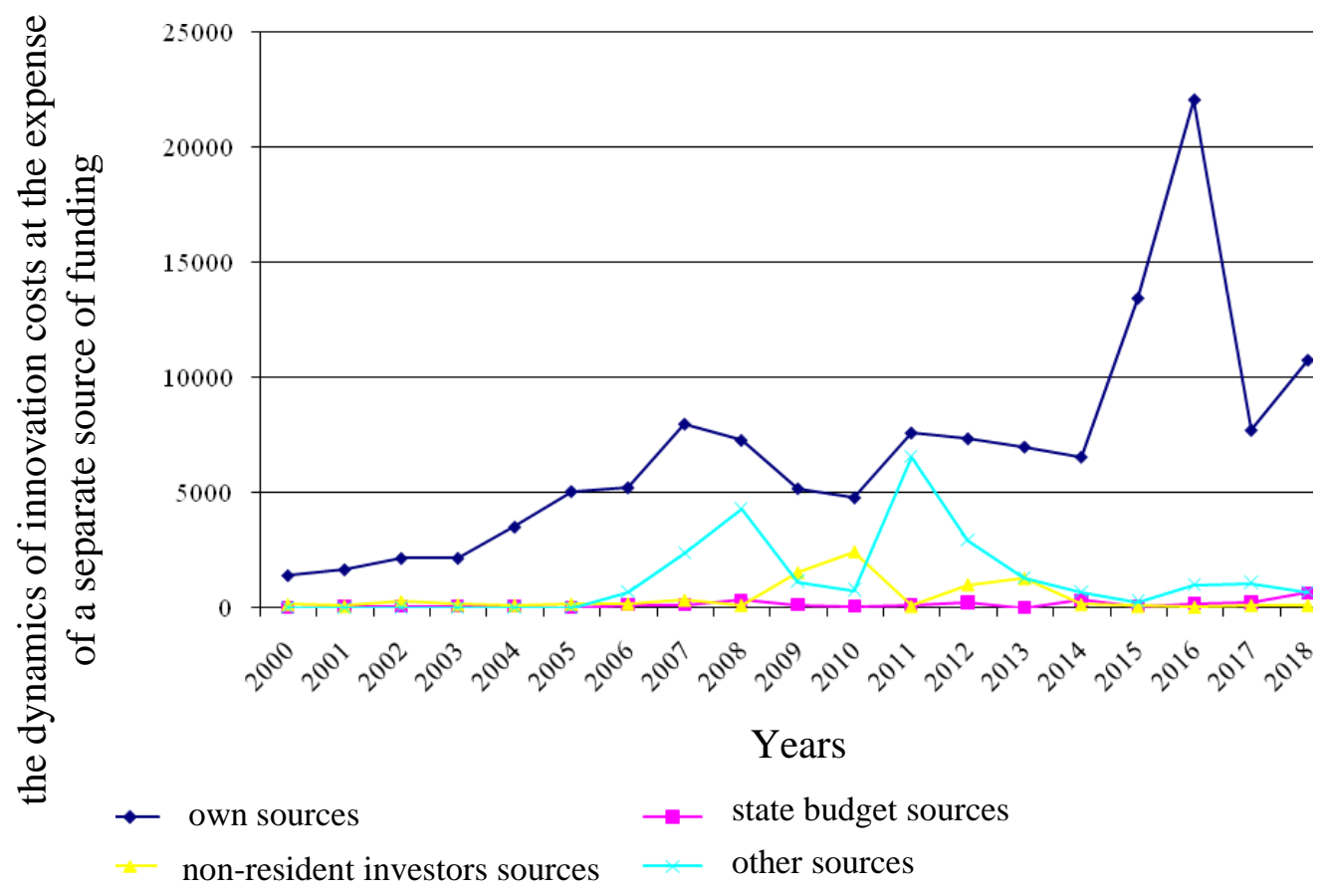

Figure 2. Dynamics of costs for innovation by sources of financing, $\mathrm{mln}$

The dynamics of other sources of financing innovation are changing less intensively. There is no cyclicality in the state budget funds, although the size of such financing is miserable.

The dynamic of innovation costs for the period 2000-2018 years is presented in Figure 3.

Today in Ukraine the innovation process is depressed. The data of the State Statistics Service of Ukraine, which show that more than 15\% of innovations are introduced in industry and other sectors of the economy, - are either imperfection of the methodology of statistical accounting, or features of reliability of statistical reporting of firms and entrepreneurs, where the wish is given as valid.

As can be seen from figure 4, with the current growth trend in the share of the number of innovation-active enterprises, there is a clear downward trend in the share of sales of innovative products, which indicates a forthcoming decline in demand for innovations, despite the growth of enterprises that introduce innovations. 


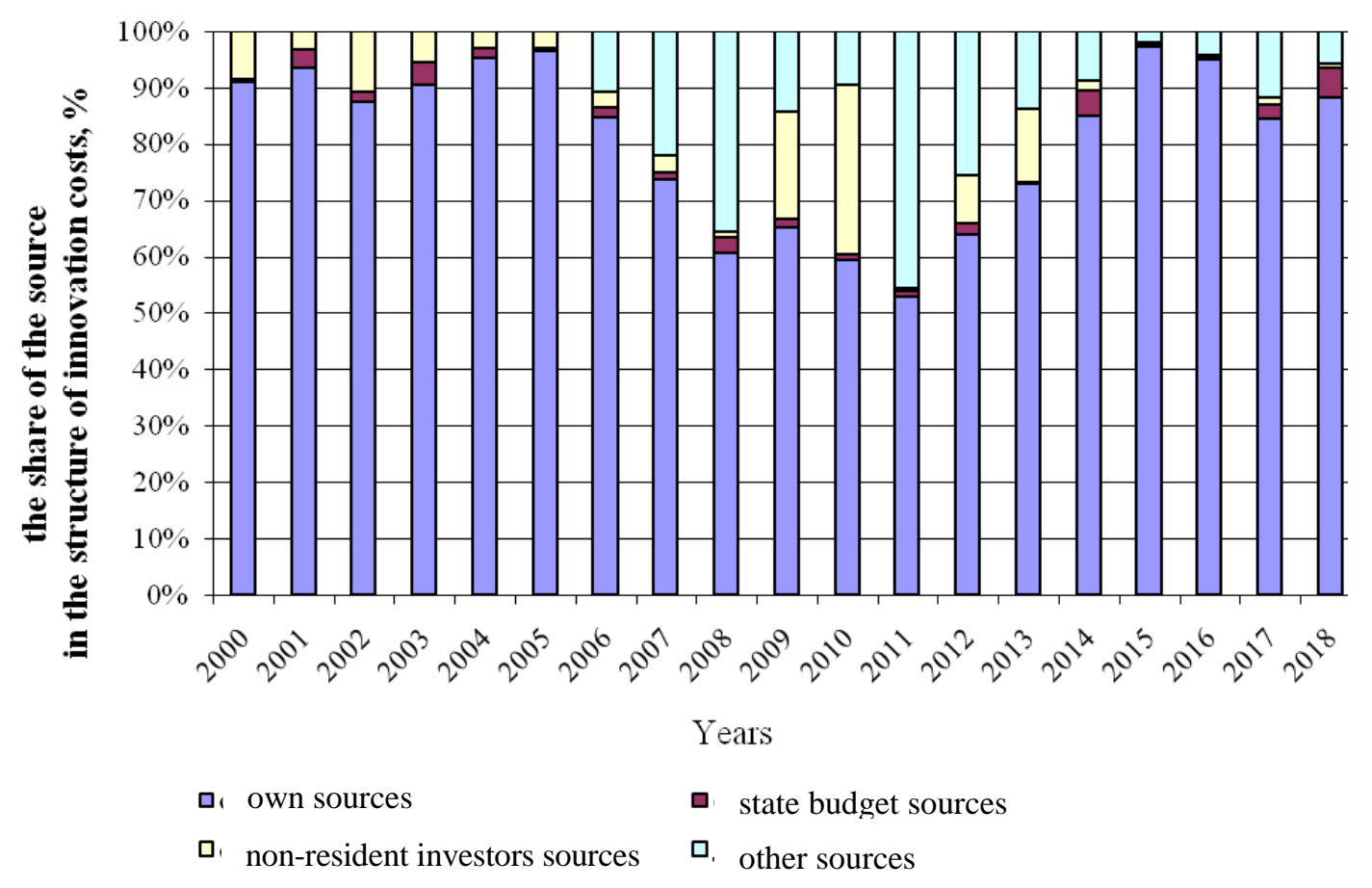

Figure 3. Dynamics of costs for innovation, $\%$

Table 7

Dynamics of indexes, characterizing functional and perspective indicators of innovation processes in Ukraine

\begin{tabular}{|c|c|c|c|}
\hline Year & $\begin{array}{c}\text { The share of the } \\
\text { number of enterprises } \\
\text { that implemented } \\
\text { innovations\% }\end{array}$ & $\begin{array}{c}\text { The share of sales of } \\
\text { innovative products } \\
\text { (goods, services), }\end{array}$ & $\begin{array}{c}\text { The share of } \\
\text { innovation active } \\
\text { enterprises, } \%\end{array}$ \\
\hline 2000 & 14,8 & 9,4 & 18,0 \\
\hline 2001 & 14,3 & 6,8 & 16,5 \\
\hline 2002 & 14,6 & 7,0 & 18,0 \\
\hline 2003 & 11,5 & 5,6 & 15,1 \\
\hline 2004 & 10,0 & 5,8 & 13,7 \\
\hline 2005 & 8,2 & 6,5 & 11,9 \\
\hline 2006 & 10,0 & 6,7 & 11,2 \\
\hline 2007 & 11,5 & 6,7 & 14,2 \\
\hline 2008 & 10,8 & 5,9 & 13,0 \\
\hline 2009 & 10,7 & 4,8 & 12,8 \\
\hline 2010 & 11,5 & 3,8 & 13,8 \\
\hline 2011 & 12,8 & 3,8 & 16,2 \\
\hline 2012 & 13,6 & 3,3 & 17,4 \\
\hline 2013 & 13,6 & 3,3 & 16,8 \\
\hline 2014 & 12,1 & 2,5 & 16,1 \\
\hline 2015 & 15,2 & 1,4 & 17,3 \\
\hline
\end{tabular}




\begin{tabular}{|c|c|c|c|}
\hline Year & $\begin{array}{c}\text { The share of the } \\
\text { number of enterprises } \\
\text { that implemented } \\
\text { innovations\% }\end{array}$ & $\begin{array}{c}\text { The share of sales of } \\
\text { innovative products } \\
\text { (goods, services), } \%\end{array}$ & $\begin{array}{c}\text { The share of } \\
\text { innovation active } \\
\text { enterprises, } \%\end{array}$ \\
\hline 2016 & 16,6 & 1,2 & 18,9 \\
\hline 2017 & 14,3 & 0,7 & 16,2 \\
\hline 2018 & 15,6 & 0,8 & 16,4 \\
\hline
\end{tabular}

For a clearer picture, we have translated the table data into a graphical dimension (Figure 4).

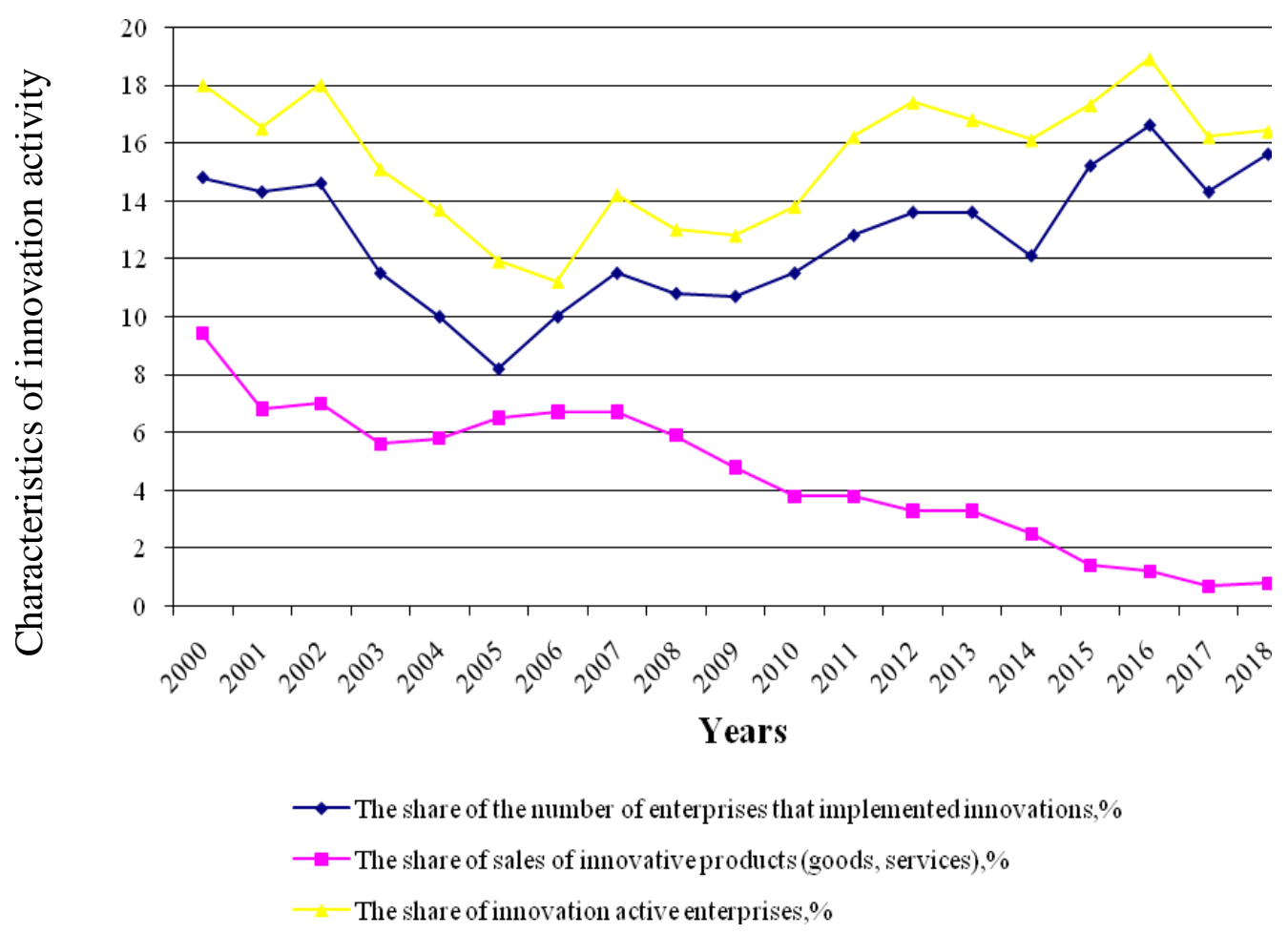

\section{Figure 4. Dynamics of indexes, characterizing functional and perspective indicators of innovation processes in Ukraine}

In general, the period from 2000 to 2018 allows us to identify only short-term cycles of development of innovative processes in the Ukrainian economy. To get a clearer picture of cyclicity and to make forecasts for the long term, it is necessary to increase the number of observations, for example, quarterly, which today causes difficulties due to the limited availability of necessary information. 


\section{CONCLUSIONS}

Thus, the great crisis potential, which manifests itself on the eve of the natural economic crisis, which our economy is entering, poses an increased risk for the innovative development of the Ukrainian economy.

Considering rather conflicting opinions of various experts, we can conclude that in the long term, seeing the intensity of innovation in developed countries, Ukraine's position among other countries cannot be called strong. Moreover, given the appearing deterioration in global markets, according to experts' forecasts, Ukraine's short-term economic growth in the innovation sector is also at risk, despite some positive trends.

Due to the fact that the developed indicators show cycles, but each in its own way, it is necessary to construct one composite of several indicators, which, thanks to generalization (averaging), will be better at predicting cycles than each separately.

The study of indicators of the cyclicality of the innovation process carried out in this work for sure leads to the idea that there is an urgent need to build a composite indicator of the cyclicality of the innovation process. The search and construction of such an indicator are one of the perspective directions for the development of scientific thought. Moreover, it is advisable to build the indicator itself according to the requirements of modern economic theory, i.e. when measuring cyclicality, it should reflect resources, results, and prospects for the development of the innovation process.

Further research is planned to be carried out in the field of determining adaptive models of each of the components of a composite indicator to determine their weight coefficients.

As the author's studies showed, an indicative analysis is the most acceptable approach for diagnosing. Thus, a detailed examination of the factors affecting the cyclical nature of innovation processes, namely, the innovation cycle itself and its amplitude, will make it possible to clarify the list of indicators, which would be necessary for evaluating and timely identifying the causes of cyclical innovation processes.

\section{SUMMARY}

The aim of this work is to systematize the development factors of the innovation process to justify the system of indicators of cyclicality, which can be used to analyze the cyclicality of the innovative process and predict their results. The paper clarifies the concepts of innovation, the innovation process, and cyclicality. Factors, influencing the 
innovation cycle and cyclicality of innovation, are systematized. A system of indicators of the cyclicality of innovative processes has been developed. The necessity of building a composite indicator of the cyclicality of the innovation process is justified. Based on the analysis of information, which characterizes the innovative processes in Ukraine from 2000 to 2018, emerging negative trends in innovative development have been identified. It has been suggested that Ukraine's short-term economic growth in the innovation sector is endangered, despite some positive trends.

\section{REFERENCES:}

1. Balashova E. (2005). Finn Kyudland i Edvard Preskott: dvizhuschie silyi eko-nomicheskih tsiklov [Finn Cudland and Edward Prescott: drivers of economic cycle]. Voprosyi ekonomiki, no. 1, pp. 133-143.

2. Beketov N.V. (2008). Tsiklichnost razvitiya ekonomicheskoy sistemyi i innovatsionnyie otnosheniya $\mathrm{v}$ konkurentnoy srede [The cyclical development of the economic system and innovative relations in a competitive environment]. Vestnik HGAEP, no. 1(34), pp. 4-11.

3. Blauh M. (2001). Ekonomichna teoriia v retrospektyvi [Economic theory in retrospect]. Kyiv : Osnovy, 672 p.

4. Derzhavna sluzhba statystyky Ukrainy [State Statistics Service of Ukraine]. URL: http://www.ukrstat.gov.ua (accessed: 07.10.2019).

5. Zamulin O. (2005). Kontseptsiya realnyih ekonomicheskih tsiklov i ee rol v evolyutsii makroekonomicheskoy teorii [The concept of real economic cycles and its role in the evolution of macroeconomic theory]. Voprosyi ekonomiki, no. 1, pp. 144-152.

6. Zarova E.V. (2010). Statisticheskie indikatoryi kratkosrochnyih ekonomicheskih tsiklov $\mathrm{v}$ razvitii regiona : monografiya [Statistical indicators of short-term economic cycles in the development of the region: monograph]. Samara : Izd-vo Samar. gos. ekon. un-ta, 215 p.

7. Kondratev N.D. (1993). Izbrannyie sochineniya [Selected Works]. Moskva : Ekonomika, 544 p.

8. Makarenko I.P. Nekotoryie instrumentyi prognoza ekonomicheskoy dinamiki i ekonomicheskih krizisov [Some tools for forecasting economic dynamics and economic crises]. URL: http://http://www.iee.org.ua/ (accessed: 10.06.2019).

9. Petuhov N.A. (2012). Innovatsionnyie faktoryi razvitiya sovremennyih ekonomicheskih sistem: avtoref. ... kand. ekon. nauk: 
08.00.05. Krasnodar. URL: http://rudocs.exdat.com/docs/index527491.html (data zvernennya: 14.11.2019).

10. Haberler G. (2005). Protsvetanie i depressiya: teoreticheskiy analiz tsiklicheskih kolebaniy [Prosperity and depression: a theoretical analysis of cyclic vibrations]. Chelyabinsk : Sotsium, 474 p.

11. Yakovets Yu.V. (1999). Tsiklyi. Krizisyi. Prognozyi [Cycles. Crises. Forecasts]. Moskva : Nauka, 448 p.

Information about the author: Verkhoglyadova N. I.

Doctor of Economics, Professor, Director of the Institute of Management, Economics, and Finance of the Interregional Academy of Personnel Management, Ukraine 